\title{
OXYGEN FUGACITY OF KIMBERLITE MAGMAS AND THEIR RELATIONSHIP TO THE CHARACTERISTICS OF DIAMOND POPULATIONS, LAC DE GRAS, N.W.T., CANADA
}

\author{
Yana Fedortchouk ${ }^{1}$, Dante Canil ${ }^{1}$ and Jon A. Carlson ${ }^{2}$ \\ ${ }^{1}$ University of Victoria, Canada; ${ }^{2}$ BHPBilliton Diamonds Inc, Canada
}

\section{INTRODUCTION}

Surface features of natural diamonds record a number of diamond destroying processes that can lead to partial or complete diamond dissolution. Diamond destructive processes can negatively impact kimberlite grade and diamond value. The most common dissolution processes are resorption of octahedron crystals to tetrahexahedron (THH) and development of etch pits. It is not well understood whether dissolution happens in the mantle source (e.g. Harris, 1987, Taylor et al., 1995) or during ascent in kimberlite magma (e.g. Robinson et al., 1989). Rates of diamond oxidation and dissolution in kimberlite are sensitive to the redox regime and temperature $(\mathrm{T})$ of the melt (e.g Arima, 1998). Comparison of diamond surface features and $\mathrm{T}$ and $\mathrm{fO}_{2}$ values in different kimberlite pipes can provide information on the nature of dissolution processes and help to predict the degree of diamond preservation in a pipe. Towards this end we estimated $\mathrm{T}$ and $\mathrm{fO}_{2}$ values of kimberlite melt and described morphology and dissolution features of diamond population from several Lac de Gras kimberlite pipes.

\section{GEOLOGY AND SAMPLES}

The Lac de Gras kimberlite field is located in the eastcentral part of the Archean Slave Province, Canada. Kimberlites have Eocene and Late Cretaceous emplacement ages (Davis \& Kjarsgaard, 1997) and intrude metamorphosed Archean sedimentary, volcanic, and plutonic rocks (Carlson et al, 1998). The majority of these pipes are filled by crater facies kimberlite intruded by hypabyssal facies magma (Kirkley et al., 1998; Pell, 1997). Diatreme facies kimberlite is rare in comparison with South African examples. This study examines fresh kimberlite sampled in drill core from six kimberlite pipes: Leslie, Aaron, Grizzly, Misery, Panda and Beartooth and diamond population from the latter three.

The Leslie, Grizzly and a part of the Aaron pipe are filled with extremely fresh macrocrystic hypabyssal monticellite kimberlite. The Panda, Misery, Beartooth and a part of the Aaron pipe are vocaniclastic kimberlites. Hypabyssal kimberlites have fresh olivine phenocrysts
$(0.2-1 \mathrm{~mm})$ with inclusions of magnesiochromite along their margins (Figure 1). Olivine phenocrysts from the more altered volcaniclastic facies kimberlites have preserved fresh cores with magnesiochromite inclusions. The presence of chromite inclusions in olivine allowed us to estimate $\mathrm{T}$ and $\mathrm{fO}_{2}$ of their co-crystallization.

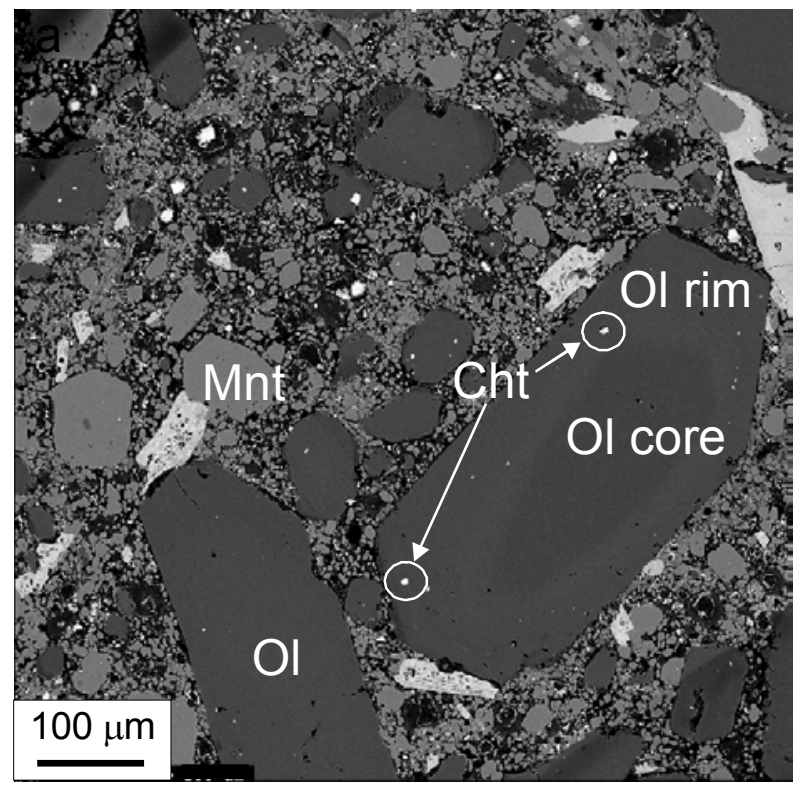

Figure 1: Back scattered electron image of the Leslie kimberlite showing euhedral chromite inclusions in margin zone of olivine phenocrysts with scale bar shown (Ol- olivine, Mnt monticellite, Cht - chromite).

\section{OI-Sp GEOTHERMOMETERY AND OXYGEN BAROMETERY}

The lack of any significant alteration in olivine phenocrysts and presence of chromite inclusions permit application of $\mathrm{Mg}-\mathrm{Fe}$ exchange thermometers and oxygen barometers to estimate the crystallization $\mathrm{T}$ and $\mathrm{fO}_{2}$ of kimberlite magma. For olivine - spinel pairs the reaction: $6 \mathrm{Fe}_{2} \mathrm{SiO}_{4}+\mathrm{O}_{2}=3 \mathrm{Fe}_{2} \mathrm{Si}_{2} \mathrm{O}_{6}+2 \mathrm{Fe}_{3} \mathrm{O}_{4} \quad$ (1)

olivine orthopyroxene chromite can be used as an oxygen barometer. An experimentallycalibrated version of this oxygen barometer developed by Ballhaus et al., (1991) requires electron microprobe data only for olivine and spinel and $\mathrm{T}$ of equilibration. Reaction (1) implies silica activity has to be buffered by 
the presence of both olivine and orthopyroxene. For orthopyroxene-undersaturated rocks the oxygen barometer gives the maximum $\mathrm{fO}_{2}$ and the required correction for such a system is approximately $-0.2 \mathrm{log}$ unit (Ballhaus et al., 1991). Temperatures were determined by olivine-spinel $\mathrm{FeMg}_{-1}$ exchange thermometer of O'Neill \& Wall, (1987) corrected and simplified by Ballhaus et al., (1991). The $\mathrm{Fe}^{3+} / \Sigma \mathrm{Fe}$ of chromites were calculated by stoichiometry using method of Droop (1987) and tested against spinels standards with $\mathrm{Fe}^{3+}$ known from Mössbauer spectroscopy (Canil and O’Neill, 1996; Canil et al., 1990). The calculated crystallization temperatures are $1000^{\circ}-1100^{\circ} \mathrm{C}+/-50^{\circ}$ (at $1 \mathrm{GPa}$ ) for margins of phenocryst olivine in samples from the Leslie, Aaron, Grizzly, Panda, Beartooth and Misery pipes. Higher temperature of $1350^{\circ} \mathrm{C}$ was recorded by olivine in the Leslie pipe. At these temperatures the $\mathrm{fO}_{2}$ recorded by coexisting olivine and chromite in the phenocrysts are 0 to $1(+/-0.4) \log$ units more oxidized than the nickel-nickel oxide (NNO) buffer (Figure 2).

Differences in T- $f \mathrm{O}_{2}$ values between the pipes are within uncertainties, but the data for each pipe cluster and may represent real differences in the emplacement conditions for each pipe. For example, the Misery pipe shows the lowest $\mathrm{fO}_{2}$ and the Panda and Beartooth pipes the lowest temperatures. Values for Grizzly and Aaron are very similar. We thus cannot estimate absolute $\mathrm{T}-\mathrm{fO}_{2}$ values for each kimberlite, but we believe that our data describes the relative difference between pipes.

The $\mathrm{T}-\mathrm{fO}_{2}$ dependence at a given $\mathrm{P}$ obtained in the present study allows us to evaluate the $\mathrm{T}-\mathrm{P}-\mathrm{fO}_{2}$ path of the Lac de Gras kimberlites. Ogasawara et al. (1997) showed that the direct oxidation of diamond into $\mathrm{CO}_{2}$

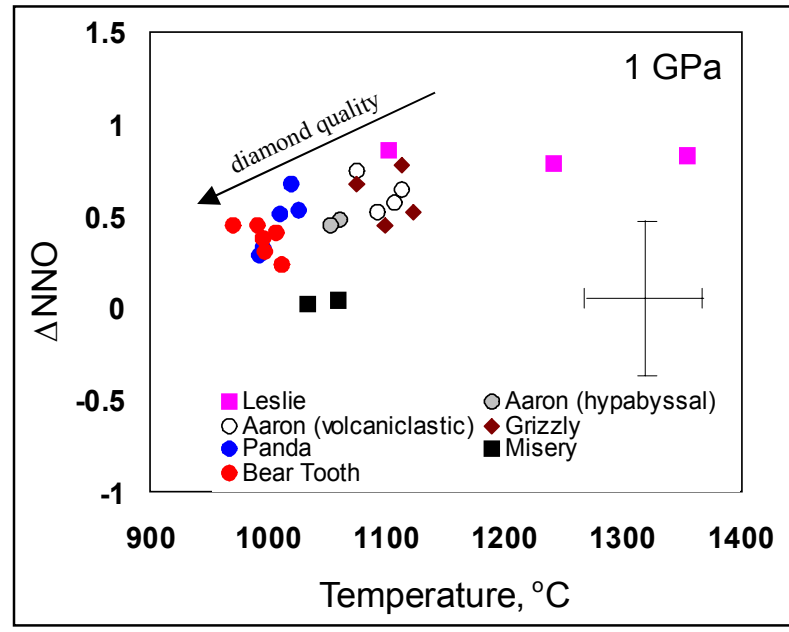

Figure 2: Oxigen fugacity and crystallization temperatures for olivine - spinel assemblages in the six kimberlite pipes. $\mathrm{fO}_{2}$ is shown in $\triangle \mathrm{NNO}$ units $\left(=\log f \mathrm{O}_{2}\right.$ sample $-f_{2}$ NNO buffer at $\mathrm{P}$ and $\mathrm{T})$. The error bars are shown. favors better preservation of diamonds than graphitization. Figure 3 shows that over a range of pressures from 3.5 to $5 \mathrm{GPa}$, the $f_{2}$ of the kimberlite melt would be $\sim 1 \log$ unit above the diamond /graphiteCO (D/GCO) buffer. During entrainment, diamonds or diamond-bearing mantle xenoliths in these kimberlites were moved into the $\mathrm{CO}_{2}$ stability field without graphitization. This path may have aided in promoting both the generally good diamond grade and quality in some of the Lac de Gras kimberlite pipes.

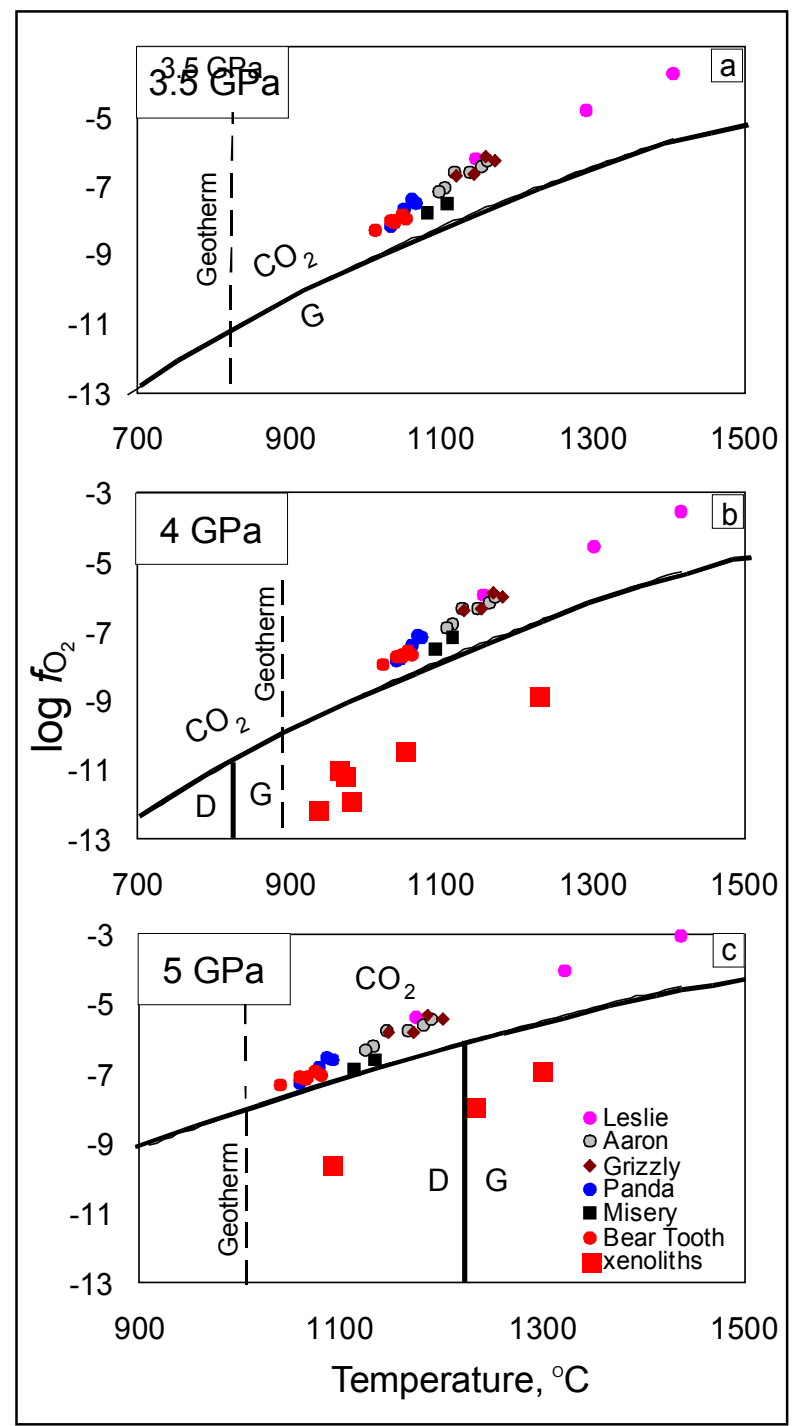

Figure 3: Stability fields of diamond (D), graphite $(\mathrm{G})$ and $\mathrm{CO}_{2}$ in $\log \mathrm{fO}_{2}$ - T space calculated at (a) $3.5 \mathrm{GPa}$, (b) $4 \mathrm{GPa}$, and (C) $5 \mathrm{GPa}$, compared to $\mathrm{T}-\mathrm{fO}_{2}$ data from six kimberlites recalculated to these pressures. The $\mathrm{fO}_{2}$ recorded by mantle xenoliths from South Africa (McCammon et al., 2001) are $3 \mathrm{log}$ units below that of kimberlites. Curves for G/DCO buffer were calculated from Frost \& Wood (1997). D/G transition is from Kennedy \& Kennedy (1976). Lac de Gras geotherm is from MacKenzie \& Canil (1999). 


\section{FEATURES OF DIAMOND POPULATION}

We examined diamond populations recovered from reverse circulation drill holes in the Panda, Misery and Beartooth pipes. The diamonds were sieved into seven classes using Tyler sieves and for each sieve class the proportion of different morphologies have been recorded as octahedrons (O - less than $50 \%$ faces resorbed), tetrahexahedrons (THH - more than $50 \%$ of faces resorbed), cubes and fragments (Table 1).

\section{Table 1: Percentages of diamonds according to morphology type from the Panda, Misery and Beartooth pipes}

\begin{tabular}{llll} 
& Panda & Misery & Beartooth \\
\hline octahedron & 59.6 & 25.6 & 46.3 \\
THH & 9.1 & 59.9 & 11.3 \\
cube & 4.3 & 4.0 & 18.4 \\
fragments & 27.1 & 10.5 & 24.0 \\
O/THH & 6.5 & 0.4 & 4.1
\end{tabular}

The degree of resorption was then calculated as the Octahedron/ THH ratio $(\mathrm{O} / \mathrm{THH})$. The proportions of stones with etch and growth features were counted (Table 2).

Table 2: Proportion of diamonds with etch and growth features among octahedron and THH stones from the Panda, Misery and Beartooth pipes

Pipe

Panda Misery Beartooth

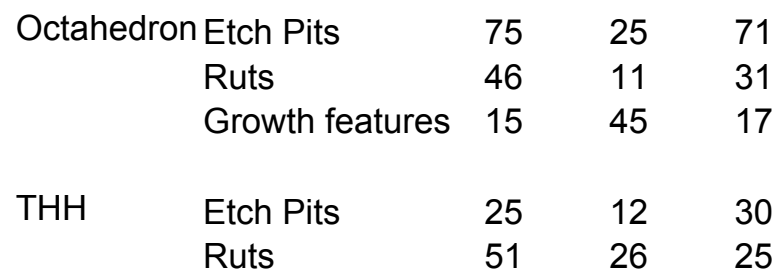

In the present study we recorded such etching features as negatively oriented trigons, hexagons, square pits and ruts shown on Figure 4.

Diamond populations from the Panda and Beartooth pipes are very similar in terms of degree of resorption and development of etch and growth surface features but are different from the Misery pipe (Table 1, 2, Figure 5).

$\mathrm{T}$ and $\mathrm{fO}_{2}$ values of the kimberlite melt in the Panda and Beartooth pipes are nearly equivalent but differ from those of the Misery pipe (Figure 2). This may indicate a possible relation between conditions in the kimberlite

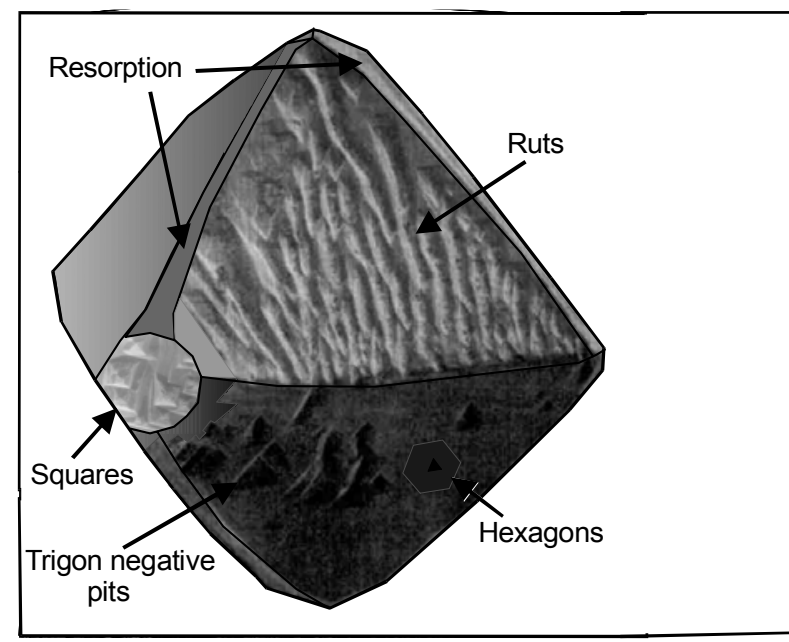

Figure 4: Different diamond destruction processes present on an octahedron diamond: beginning of resorption into $\mathrm{THH}$ and etching surface features (negative trigon pits, squares, hexagons and ruts). The picture combines photos from Afanasiev et al., 2000).

melt and characteristics of diamond population. The Misery pipe has diamonds with a much higher degree of resorption than the Panda and Beartooth stones yet the lowest $\mathrm{fO}_{2}$ values. This correlation is inconsistent with the presence of THH forms resulting from conditions in the kimberlite melt. We cannot resolve this paradox in the present study and more data from different kimberlite pipes are needed. The proportion of octahedrons and THH with etch pits and ruts, and their distribution among sieve sizes in the Panda and Beartooth populations is similar (Table 2, Figure 5). Misery diamonds have fewer etch features but the Misery population has a higher porportion of stones with growth features. Detailed diamond descriptions were not performed for the Grizzly pipe, but overall the quality of stones in this pipe is much poorer. Our preliminary results show that some characteristics of diamond populations (e.g morphology and surface features) may be related to $\mathrm{fO}_{2}$ conditions in the melt.

\section{CONCLUSIONS}

1. Inclusions of chromites in margin zones of olivine phenocrysts in hypabyssal and volcaniclastic kimberlites from the Leslie, Aaron, Grizzly, Panda, Beartooth and Misery in the Lac de Gras area allowed to use Ol-Sp thermobarometry. The olivine margines crystallized from kimberlite melt at $1000^{\circ}-$ $1100^{\circ} \mathrm{C}$ (calculated at $1 \mathrm{GPa}$ ) and 0 to $+1 \log$ unit above NNO buffer. 
2. The $\mathrm{T}-\mathrm{fO}_{2}$ values obtained for the six Lac de Gras kimberlites show that the diamonds entrained in these kimberlites ascended in the stability field of $\mathrm{CO}_{2}$ without graphitization. Such a $\mathrm{T}-\mathrm{fO}_{2}$ path favored better preservation of diamond quality and grade.

3. Kimberlite pipes with better quality diamonds have $\mathrm{fO} 2$ and $\mathrm{T}$ values lower relative to the pipes with poorer stones. This may indicate a relationship between the conditions in kimberlite melt and features of the diamond population.

4. The Misery pipe with the lowest $\mathrm{fO}_{2}$ has the highest degree of resorption, but a relatively low proportion of stones with etch pits. Further study is required to better understand which of the diamond dissolution processes is controlled by the redox regime in kimberlite melt during ascent.

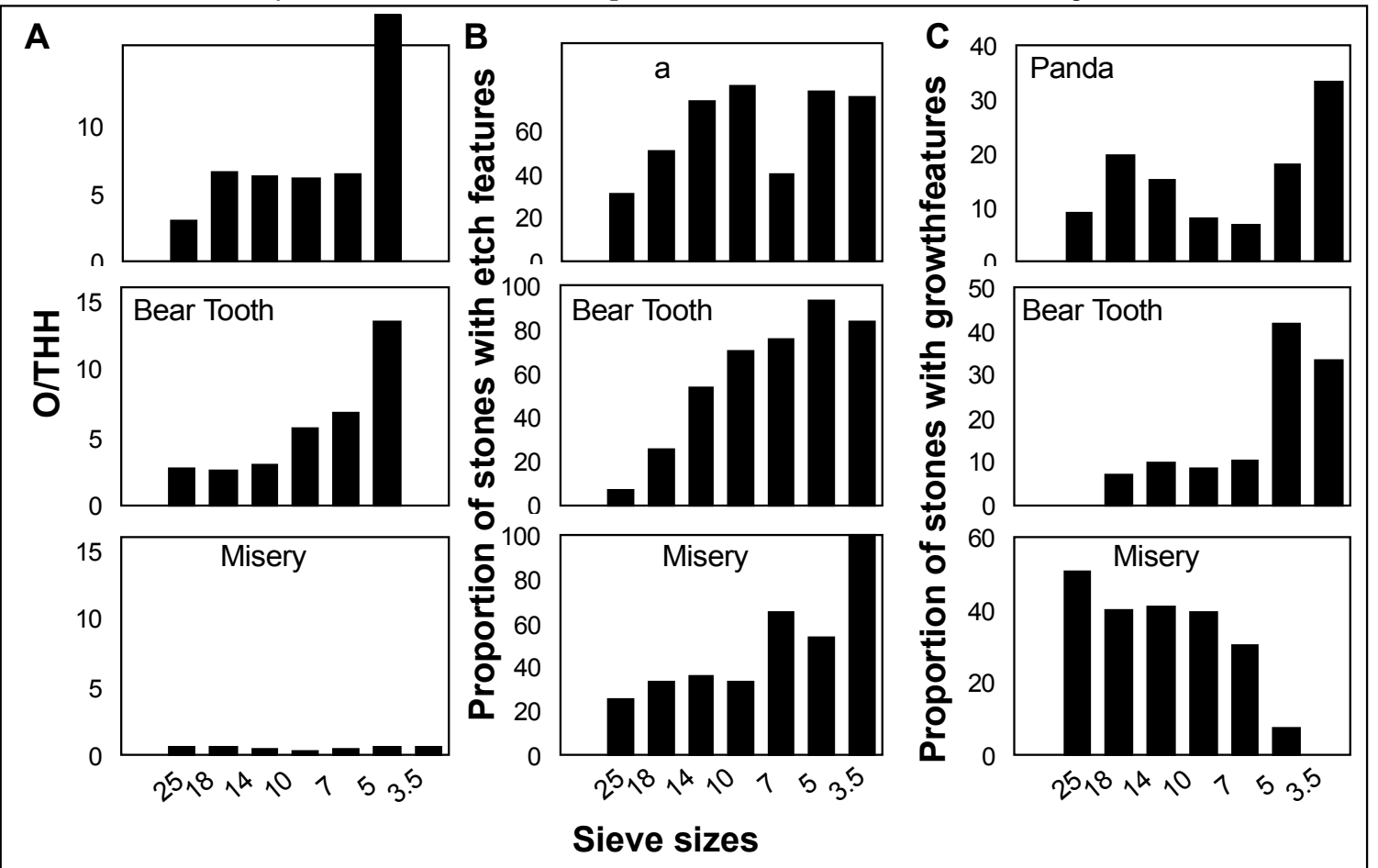

Figure 5: (a) Distribution of O/THH ratio values as measure of degree of resorption and (b) proportion of diamonds with etching and (c) growth features among sieve sizes in the Panda, Misery and Beartooth kimberlites. The plot shows similarities in the characteristics of the Panda and Beartooth diamond populations and differences with the Misery diamonds.

\section{REFERENCES}

Afanasiev, V.P., Yefimova, E.S., Zinchuk, N.N., Koptil, V.I., 2000. Atlas of morphology of diamonds from Russian sources. SPC UIGGM, SB RAS, Novosibirsk.

Arima, M., 1998. Experimental study of growth and resorption of diamond in kimberlitic melts at high pressures and temperatures, 7th Internat. Kimberlite Conference, Cape Town, pp. 32-34.

Ballhaus, C., Berry, R.F. and Green, D.H., 1991. High pressure experimental calibration of the olivine-orthopyroxenespinel oxygen geobarometer: Implications for the oxidation state of the upper mantle. Contributions to Mineralogy and Petrology, 107: 27-40.

Canil, D. and O'Neill, H.S.C., 1996. Distribution of ferric iron in some upper mantle assemblages. J. Petrol., 37: 609-635.

Canil, D., Virgo, D. and Scarfe, C.M., 1990. Oxidation states of mantle xenoliths from British Columbia, Canada. Contrib. Mineral Petrol., 104: 453-562.

Carlson, J.A., Kirkley, M.B., Tohomas, E.M. and Hillier, W.B., 1998, Recent Canadian Kimberlite Discoveries. $7^{\text {th }}$ Internat. Kimberlite Conference Proceedings, Cape Town, V.1, pp. 81-89.
Davis, W.J. and Kjarsgaard, B.A., 1997. A Rb-Sr Isochron age for kimberlite from the recently discovered Lac de Gras Field, Slave Province, Northwest Canada. Journal of Geology, 105: 503-509.

Droop, G.T.R., 1987. A general equation for estimating Fe3+ concentrations in ferromagnesian silicates and oxides from microprobe analyses, using stoichiometric criteria. Mineralogical Magazine, 51: 431-435.

Frost, D.J. and Wood, B.J., 1997. Experimental measurments of the fugacity of $\mathrm{CO} 2$ and graphite / diamond stability from 35 to $77 \mathrm{kbar}$ at 925 to $1650^{\circ} \mathrm{C}$. Geochimica et Cosmochimica Acta, 61(8): 1565-1574.

Harris, J.W., 1987. Recent physical, chemical, and isotopic research of diamond. In: P.H. Nixon (Editor), Mantle xenoliths. John Wiley and Sons Ltd, Chichester, pp. 477500.

Kennedy, C.S. and Kennedy, G.C., 1976. The equilibrium boundary between graphite and diamond. Journal of Geophysical Research,, 81(14): 2467 - 2470.

Kirkley, M.B. et al., 1998. Kimberlite emplacement processes interpreted from Lac de Gras examples, 7th Internat. Kimberlite Conference, Cape Town, pp. 429-431. 
MacKenzie, J.M. and Canil, D., 1999. Composition and thermal evolution of cratonic mantle beneath the central Archean Slave Province, NWT, Canada. Contributions to Mineralogy and Petrology, 134: 313-324.

McCammon, C.A., Griffin, W.L., Shee, S.R. and O'Neill, H.S.C., 2001. Oxidation during metasomatism in ultramafic xenoliths from the Wesselton kimberlite, South Africa: implications for the survival of diamond. Contributions to Mineralogy and Petrology, 141: 287296.

Ogasawara, Y., Liou, J.G. and Zhang, R.Y., 1997.

Thermochemical calculation of log fO2 - T-P stability relations of diamond-bearing assemblages in the model system CaO-MgO-SiO2-CO2-H2O. Russian Geology and Geophysics, 38(2): 587-598.

O'Neill, H. and Wall, V.J., 1987. The olivine-orthopyroxenespinel oxygen geobarometer, the nickel precipitation curve, and the oxygen fugacity of the Earth's upper mantle. J. Petrol., 28: 1169-1191.

Pell, J.A., 1997. Kimberlites in the Slave Craton, Northwest Territories, Canada. Geoscience Canada, 24: 77-90.

Robinson, D.N., Scott, J.A., Neikerk, A.V. and Anderson, V.G., 1989. The sequence of events reflected in the diamonds of some southern African kimberlites, Kimberlites and related rocks, pp. 990-1000.

Taylor, W.R., Bulanova, G. and Milledge, H.J., 1995. Quantitative nitrogen aggregation study of some Yakutian diamonds: constraints on the growth, thermal, and deformation history of peridotitic and eclogitic diamonds, 6th International Kimberlite Conference, Novosibirsk, pp. 608-610.

Contact: Y Fedortchouk, School of Earth and Ocean Sciences, University of Victoria, PO Box 3055 STN CSC Victoria, BC, Canada, V8W 3P6, E-mail: yana@uvic.ca 